\title{
Occupy and the constitution of anarchy
}

\author{
R U T H K I N N A
}

Department of Politics and International Studies, Herbert Manzoni Building, Loughborough University, Leicestershire LE11 3TU

Email: r.e.kinna@lboro.ac.uk

\author{
A L E X P R I C H A R D \\ Department of Politics, Amory Building, University of Exeter, Rennes Drive, Exeter EX4 4RJ
}

Email: a.prichard@exeter.ac.uk

TH O M A S W A N N

Department of Politics and International Studies, Herbert Manzoni Building, Loughborough University, Leicestershire LE11 $3 T U$

Email: t.swann@lboro.ac.uk

\begin{abstract}
This article provides the first comparative reading of the minutes of the General Assemblies of three iconic Occupy camps: Wall Street, Oakland and London. It challenges detractors who have labelled the Occupy Wall Street movement a flashin-the-pan protest, and participant-advocates who characterised the movement anticonstitutional. Developing new research into anarchist constitutional theory, we construct a typology of anarchist constitutionalising to argue that the camps prefigured a constitutional order for a post-sovereign anarchist politics. We show that the constitutional politics of three key Occupy Wall Street camps had four main aspects: (i) declarative principles, preambles and documents; (ii) complex institutionalisation; (iii) varied democratic decision-making procedures; and (iv) explicit and implicit rule-making processes, premised on unique foundational norms. Each of these four was designed primarily to challenge and constrain different forms of global and local power, but they also provide a template for anarchistic constitutional forms that can be mimicked and linked up, as opposed to scaled up.
\end{abstract}

Keywords: anarchism; constitutionalising; Occupy Wall Street Movement; power

\section{Introduction}

Anarchism is rarely if ever discussed in the context of constitutional politics. Indeed, anarchist activists rarely understand their activities in these terms 
either. In this article we show that anarchist political thought and practice is at its heart a post- or anti-statist and anti-capitalist constitutional politics, and we do so through a contextual analysis of organisational structure and democratic process of three iconic Occupy camps. We argue that the anarchist constitutional politics of Occupy was designed primarily to challenge and constrain different forms of global and local power, while providing a template for anarchistic constitutional forms that can be mimicked and linked up, as opposed to scaled up.

Occupy has attracted enormous scholarly attention, but has never been discussed as an exemplar of anarchist constitutional politics. It has been lauded for rethinking political subjectivity and space; developing the language of occupation; for revivifying the language of class; popularising prefigurative politics, while refusing to make demands of the state; institutionalising protest; developing diffused media messages through online networks; and drawing attention to protest policing (Pickerill and Krinksy 2012. See also Halvorsen 2012, 2014, 2015; Arenas 2014; Rossdale and Stierl 2016; Costanza-Chock 2012; Adi 2015; Swann and Husted 2017; Hammond 2015; Savio 2015; Gerbaudo 2017). These issues are germane to constitutional politics but the dominant frameworks adopted by critics and proponents alike badge them as expressions of the resistance or protest politics of the time or as real democracy.

Academic commentary on Occupy on the mainstream left was scathing and remains so to this day. In their influential work Inventing the Future, Nick Srnicek and Alex Williams (2015) argued that the Occupy movement was a backward-looking form of 'folk politics' that celebrated the local and the counter-cultural, but failed to enact more than a modicum of consciousness-raising. Jodie Dean, and the co-contributors to Socialist Register (2013), praised Occupy for re-establishing the concept of class in the American political lexicon but bemoaned the inability to advance a vanguardist party politics capable of coordinating the left 'crowd' or 'swarm' and providing a consolidated challenge to political power (Dean 2016). Like Paul Mason (2016), many were highly sympathetic to the networks of activism that spanned the globe during those few months at the end of 2011, but none grasped the constitutional moment that galvanised it.

Indeed, even Occupy's anarchist architects rejected the argument that the camps were an experiment in constitutional politics, because they conflated existing constitutional arrangements in the United States with constitutional politics as such. As Howard and Pratt-Boyden (2013: 734) argued, the practice of 'real' democracy - the implementation of consensus decision making - was the most visible demonstration of the occupiers' rejection of 'the current constitutional models'. David Graeber's The Democracy Project (2013), an account of Occupy Wall Street and one of the most 
comprehensive first-hand analyses of any of the camps, promotes the same opposition (see also Bray 2013; Schneider 2013). Graeber finds the precursor for Occupy Wall Street in Tom Paine's popular democratic movement against the Founding Fathers. He thus paints the US constitution as the tool of a white male elite who thought itself 'wiser and better able to understand the people's true interests than the people themselves' (Graeber 2013: 160), and Occupy as a new expression of peoples' historic anticonstitutional campaign. Distracted by the arguments for 'real' democracy at the heart of Occupy, Hardt and Negri (2017) understandably lament the absence of an institutional or constitutional politics amongst the 'leaderless left' and argue that now is the time for its theorisation given 'the effectiveness of and existing conditions to support nonsovereign political institutions and democratic organizations' (Hardt and Negri 2017: 45; cf. Waldron 2016). We agree, but this model is hiding in plain sight.

The aim of this article is to challenge this narrative of a protest politics against constitutional democracy and show that there exists within the Occupy Wall Street movement a tried and tested, if imperfect, praxis for a grass-roots, post-statist constitutional politics. We provide an original analysis of the General Assembly minutes of three of the most iconic camps of the Occupy movement: Wall Street, Oakland and London. ${ }^{1}$ Building on burgeoning work in this area (Chambost 2004; Cagiao y Conde 2011; Kinna and Prichard forthcoming), our aim is to shed new light on the distinctive features of the anarchist constitutional politics of the Occupy Wall Street movement.

We show that the anarchism at the heart of Occupy was rarely if ever articulated as such. But in practice, Occupy modelled a distinctively anarchist process to the extent that it identified and challenged arbitrary 'regimes of domination' that structure global politics (Gordon 2008: 33. cf. Pettit 1997). The anarchist constitutional politics that emerged sought to challenge and equalise global power imbalances at the point of their everyday intersection, in the camps that were set up to challenge the egregious power imbalances of

1 These minutes were downloaded from the following sources: Occupy Wall Street: nycga. cc (no longer available, archived version available at <web.archive.org/web/20111004182112/ http://nycga.cc/>); Occupy Oakland: <www.occupyoakland.org>; Occupy London: <www. occupylondon.org.uk>. These have all since been archived by Loughborough University and can be accessed at: $<$ https://repository.lboro.ac.uk/articles/Anarchy_as_Constitutional_ Principle_Constitutionalising_in_Anarchist_Politics_Occupy_data/7976435/1>. OWS was the first of the movement occupations and its Principles of Solidarity and the Declaration of the Occupation of New York, as well as the anarchist decision-making and constitutional practices, were mimicked by 1000 camps worldwide. London was an important example, not only as it was one of the longest-standing camps, but also because it disavowed anti-capitalism, refused the anarchist label, and yet mimicked the constitutional, democratic and institutional features of Occupy Wall Street. Occupy Oakland was arguably the most explicitly anarchist of the iconic camps, but was also unique in terms of its local race and class politics. 
global order. The constitutional moment consisted in four primary aspects: (i) declarative principles, (ii) institutions, (iii) decision-making procedures, and (iv) formal and informal camp rules, a typology we draw from contemporary constitutional political theory and the history of anarchist constitutional practice.

Our descriptive claim is that the Occupy camps were microcosmic anarchies in which participants took account of the global regimes of domination that intersected in their emergent collective identities, forging the 'we' of the camps. Occupiers took strength from their opposition to global capitalism, challenged corrupt local and global structures of political power, and sought to counter the legacy of colonialism and the transatlantic slave trade, patriarchy and class, to enact 'the new in the shell of the old' as the Industrial Workers of the World (IWW) slogan goes. ${ }^{2}$

Occupy has not been read or discussed in terms that would resonate with scholars of global constitutionalism. In this article we do so in three parts. Part II of the article begins with a critical genealogy of the relationship of anarchy to the constitution. This provides us with a model for thinking about anarchist constitutionalising. Part III explains our methods. Part IV opens with an analytical account of the problem activists faced in the camps: power. This was understood in plural ways, issuing in plural constitutional practices. This leads us to explore in detail the constitutional practices of three of the most iconic camps of the Occupy movement. In the conclusion we reflect on the relevance of this research to wider debates on the left about the difficulty of 'scaling up' anarchist constitutional politics, and make the case for more sustained research and debate on this topic.

\section{Anarchy and the constitution}

Anarchist constitutionalism is an oxymoron for most. An anarchic constitution is not a constitution at all. Anarchy is what constitutions deliver us from. So embedded are contractarian ideas such as this that any attempt to theorise an anarchist constitutionalism endures the weight of academic and public consensus against it. For example, Loughlin (2014) argues that constitutional pluralism is an oxymoron, which suggests that a more radical anarchist account would be no less problematic.

2 In advancing this argument, we are not suggesting that participants would either agree that their activity was constitutional or that they actually used the language of constitutionalism to reconstitute a new kind of polity. Indeed, the priority attached to democracy and the critique of constitutions was problematic from the point of view of the enactment of an anarchist constitutional politics. Rather, our aim in this article is to affirm the practices of the anarchists and non-anarchists of the Occupy Wall Street movement, in order to develop new vistas for post-sovereign constitutional politics. 
The popular view was neatly summed up by Lord Rippon (1990), architect of the UK's entry in the European Communities Act 1972, who once perhaps prophetically observed that 'we are all horrified by anarchy in our streets. We should be increasingly concerned by constitutional anarchy in our parliament.' (Rippon 1990) However, the account of anarchy assumed in this standard formulation usually relies on an a priori commitment to the imagined state of nature, the need for territorially unified political communities, and a final point of authority, rather than an empirical assessment of the constitutional forms of any actually existing anarchist communities.

Many might also object to the recovery of any constitutional politics to redress our contemporary ills, let alone an anarchist constitutional politics. The empirical contingency of existing constitutions has been radically politicised by theorists of the 'new constitutionalism'. For example, the liberal republican constitutional politics animating the European Union has been attacked by democratic theorists who see the sovereignty of national parliaments undermined by the extension of human rights, democracy and rule of law to transnational bodies (Bellamy and Castiglione 2013). The globalisation of this three-part constitutional order, via the UN and other multilateral bodies, is argued to have on the one hand removed the ability of democratic constituencies to shape their own fates (Gill and Cutler 2015; Brown 2012), at the same time that the extension of the European moment to the global level replicates a decidedly colonial politics (Tully 2002a, 2002b, 2007). Not only is the constitutional defence of private property, parliamentary sovereignty, the rule of law and human rights more often than not a tool of expropriation in the global south (Springer 2011a), it also produces very particular types of neoliberal political subjects (Hardt and Negri 2000, 2009). Throughout this literature is a concern with the proper limit to either constituent power (the demos) or constituted power (see Loughlin and Walker 2007), and a concern that with every attempt at post-statist constitutionalism, much like the concern with cosmopolitan democracy in the 1990s, the power of the demos is in fact diminished. But as Hans Lindahl has argued, the very possibility of the intentional, first person plural 'we' demands a universally contingent democratic constitutionalism (Lindahl 2007).

So where do the anarchists stand in this narrative? The anarchists were never beholden to territorially demarcated nation states, and presupposed and defended the sovereign ' $\mathrm{I}$ ' as the basis for developing any first person plural 'We' (Kinna 2015). Decentralised federalism was the organisational form through which individuals and collectives generated plural 'demoî' (Bohman 2007; Prichard 2017). But with the notable exception of Pierre-Joseph Proudhon, anarchists have been reluctant to 
use the language of constitutionalism when discussing their politics (Prichard 2013).

Anarchists drew on the republican critique of slavery and domination to pinpoint three major flaws in the practices of liberal and republican constitutional regimes (for a full exposition of this argument see Kinna and Prichard, forthcoming). First, the invocation of popular sovereignty was routinely combined with the exclusion of citizens from the constitutional councils charged with deliberating and proposing constitutional provisions (see also White 2017: 325). Closed constitutional councils symbolised the hijacking of the power of the people by its self-appointed representatives the power of the legislative (Proudhon 1989/1851). The result was that the constitutions were not merely routinely and unduly influenced by elites, but purposefully designed to safeguard their interests.

This diminution of citizen power was linked to a second failing: the forms of government liberals and republicans adopted. Finding that modern states were too large and too complex to enable direct government by the people, constitutional designers resurrected the idea of representation, once used by the Third Estate to check the power of absolute monarchs, to remove the people from government and cement the power of their representatives over them (see also Tuck 2015). For anarchists, the condition was more permanent and fundamental. The gradual democratisation of representative government gave the people the illusion that it exercised authority through the power of the vote while all the time ensuring that the inequalities that constitutions regulated, in particular private property, were kept from review (Proudhon 1994 [1840]; Kropotkin n.d [1885]; 1988 [1886]).

Third, historical anarchists acknowledged that constitutions constrained power and they distinguished progressive liberal and republican from autocratic regimes on this basis. There was a 'but', however. The background conditions that structured institutional power expressed what Proudhon called social antagonism (Proudhon 1979 [1863]) and what Marx and Engels (1848) called class conflict. Whether or not individuals were understood to possess pre-political rights, republican and liberal constitutions uniformly embedded inequality. In calling a people forth, they routinely enshrined the right to private property, property in the self and the right to sell or transfer one's own property as an inviolable normative foundation of modern society. Constitutional orders were designed primarily to restrict any tyrannous majority from overturning this foundational normative order (see also Gill and Cutler 2015). Republicans and liberals drew on ideas of fairness and rational argument to mollify egregious inequality and develop grounds for democratic political power, but this did not change the fact that the rights constitutions protected were guarantees of fundamental injustice. There could be no equality between citizens in 
the presence of private property and domination was therefore structurally entrenched. In America, as in Russia, the state sold vast tracts of land to entrench the advantage of elites (Kropotkin 1988 [1887]), converting chattel slavery and serfdom, slowly into wage slavery. Compensation to slave owners entrenched these inequalities. State resources were deployed to protect minority rights to private property ownership. As Emma Goldman argued of the 1892 Homestead strike, where the militia was called in to protect Andrew Carnegie's steel interests, the distinction republicans drew between political right and force was blurred (Goldman 1979 [1892]).

The critique of private property and the structural inequalities it supported encouraged anarchists to argue that capitalist power relations fatally compromised bourgeois constitutions. They concluded that the eradication of class privilege through fundamental economic reorganisation demanded political reconstitution. As Kropotkin (1906: 46) put it: 'it would be impossible to touch private property unless a new mode of political life be found at the same time'.

But far from rejecting constitutions as such, anarchists combined the rejection of the liberal republican constitutions with the embrace of a pluralist constitutional politics. When Siegmund Engländer, the sometime partner of the news agency pioneer Julius Reuter, argued that 'the sovereign people had no right to prescribe a limit to the sovereignty of the people' and that 'every constitution was such a limit', his rejection of the constitution seemed total (Engländer 2015 [1873]: 26). Yet Engländer was a Proudhonist and he in fact wanted to anarchise the republican constitution. To this end, he argued for the replacement of the 'political' with the 'social' constitution, a demand for the constitutional recognition of all the constituent political communities, as well as the rights of all individuals.

Constitutions should safeguard institutions that 'centralised', as Engländer put it, 'from the bottom up' (Engländer 2015 [1873]). In Proudhon's terms, a federal constitution is one in which the 'the centre is everywhere, circumference nowhere. This is unity.' (Proudhon cited in Vincent 1984: 215). Likewise for Kropotkin, political community was grounded on 'free agreement' to promote the citizen-led constitutional initiatives (1906 Chs 3; 11), what Proudhon called pacts (Proudhon 1979). Free agreement was the necessary complement to the organisational initiative, decentralised federation, which virtually all anarchists after Proudhon recommended as a framework for constitutional orders, particularly in the iconic mass revolutionary syndicalist Unions of the twentieth century (Bakunin 1972 [1895]; Berneri 1942; Walter 1969; Ward 2004). From the Confederación National de Trabajo (CNT) in Spain to the longshoremen of the Regional Workers' Federation of Argentina (Federación obrera regional argentina, or FORA), to the micro unions of today like Solidarity Federation and the 
Anarchist Federation, millions of anarchists have been willing participants in anarchist constitutionals orders (de Laforcade 2010; Hirsch and van der Walt 2010; Kinna 2019).

Federalism is the central constitutional concept of this anarchosyndicalist movement, the majority organisational structure of anarchist politics from the 1880s through to the present day. While this current has tended to unduly eclipse other forms of anarchist organisation (see Swann and Stoborod 2014, for a recent discussion), it is nevertheless instructive. Maximov's Program of Anarcho-Syndicalism is an example of an anarchist labour constitution that describes an institutional design, rule and decision-making process (Maximov 1985 [1927]; see also Hirsch and van der Walt 2010; van der Walt and Schmidt 2009; Bantman and Berry 2010). Despite Murray Bookchin's (1993) vocal objection to syndicalism as a revolutionary strategy and mode of governance, his democratic confederalism dovetails with these antecedent forms; he observed that Catalan anarchists organised in the CNT adopted confederalism in the 1930 s to promote internationalism and resist nationalist trends in the region (Bookchin 1995: 72). That Bookchin's confederalism has now been adapted by Abdullah Ocalan and the YPG/YPJ in Rojava demonstrates its contemporary geopolitical usefulness (Knapp, Flach and Ayboga 2016).

But what are constitutions and how might we theorise from this practice to constitutional theory, making room for anarchism therein? Constitutional politics is primarily a rules-based, democratic and institutionalist approach to the problem of political power, broadly conceived. As Robert Goodin expressed it: 'The problem of a liberal commonwealth is how to control the abuse of power' (Goodin 1996: 635; cf. Pettit 1997: 173). The negative aspect has a positive corollary in nineteenth and twentieth century European constitutional practice. Here, constitutions are conceived as means to empower citizens and provide provisions and safeguards guaranteeing the social goods necessary to make the most of negative freedoms from autocratic power. A social democracy is a constitutional order, whether there is a written constitution or not. As Dario Castiglione explains: 'a constitution constitutes a political entity, establishes its fundamental structure, and defines the limits within which power can be exercised politically' (1996: 421-2). It is not simply a set of rules; it makes a political community, constraining and reflecting, both epistemically and then materially, the scope of the politically possible. There is no necessary form of constitution, rather myriad experiments in constitutionalism limit existing power in specific contexts.

Castiglione reminds us that republican and liberal constitutional traditions vary significantly. Fundamental to the republican constitution was the 'document establishing the form of the state and the structure of governance' 
and the 'complex of its institutions' (Castiglione 1996: 433). The characteristic three-pronged strategy republicans adopted to restrain power was to distinguish the power of the legislator (linked with sovereign people) from the power of the legislative (the peoples' representatives); embody this power in physical institutions where powers are separated; and differentiate political power from mere force. Thus, while the republican constitution enabled a democratic counter-power, liberal constitutions instead limited public power by conferring 'rights and privileges against the sovereign', delimiting a zone of non-interference, and separating the sovereign from the judiciary. Paramount was the rule of law as the guarantor of individual rights and the doctrine of the separation of powers (Castiglione 1996: 431).

Yet important as these disputes were, they reveal something fundamental about the underlying structures of constitutions. Primarily constitutions limit power, but they do so via four convergent processes: (i) declarative principles and documents calling the 'we' into being; (ii) an institutional design to balance or separate powers; (iii) rule-making processes which depersonalised power; and (iv) decision-making procedures to articulate the voice of the demos. These were modified over time, particularly with the democratisation of regimes, but each featured in the new constitutional politics. It is this basic formulation, and its anarchist heritage and form that we find in the Occupy Wall Street movement too.

\section{Occupy and anarchism}

Using Occupy to examine anarchist constitutional practices poses significant problems of selection and classification. As The Guardian reported in November 2011, after the crackdown on US Occupy camps had begun, the scale of Occupy was estimated at ' 951 cities in 82 countries'. The Guardian managed to plot 750 camps. Over two-thirds were in the USA but by any standards Occupy was a large, global movement. In terms of camp membership, it was also a plural movement. No camp was typical and not all Occupy participants identified as anarchist. The ' $A$ ' word barely features in the formal General Assembly (GA) minutes, one of the key primary sources on the movement; indeed, significant currents in the London camp, for example, even resisted the label 'anti-capitalist'. To address these issues we discuss the sense in which we are treating the camps as anarchist and then turn to our methods to clarify what we are attempting to draw from the GA minutes.

Our starting point is the research that suggests that Occupy emerged from anarchist scenes. A significant proportion of the activists who answered the Adbusters' call that sparked the first protests in Lower Manhattan were anarchist. Of the 192 main organisers of Occupy Wall 
Street (OWS) interviewed by Mark Bray, 39 per cent identified as anarchist. Another third identified as anarchistic in some way. Of those who refused the label, Bray notes that it 'was nearly impossible to describe one's politics in terms of the movement without situating them in relation to anarchism' (Bray 2013: 42). Well-organised anarchists in New York took the lead setting up the format and methods of the New York GA in the early weeks of the Zuccotti encampment (Schneider 2013: 13-14).

In a more general sense, too, Occupy drew members from European subterranean movements in which anarchistic political cultures were deeply engrained (Kaldor et al. 2012; Maiguashca, Dean and Keith 2016). Although the antecedents of the movement are much debated (Kerton 2012; Bassett 2014: 892; Hammond 2015), one strong narrative of the movement is that Occupy formed a nodal point in a historic and transnational circuit of power, linked controversially to the Arab Spring, the Spanish Indignados and the $15 \mathrm{M}$ protests, or to historic manifestations of the new left such as the Prague Spring and the Velvet Revolution. In these trajectories, Occupy materialises as an expression of the 'anarchist sensibility' that Barbara Epstein (2001) discussed in the late 1990s and early 2000s when the alter-globalisation movement mobilised. Occupy's resurrection of the social justice campaign slogan 'this is what democracy looks like' to express its primary commitments was the most obvious indicator of this inheritance. The traditions the movement absorbed were organisational rather than ideological and as porous to varieties of Marxism, autonomism, peace activism and feminism as they were to self-identifying anarchists.

Thus in calling on President Obama to set up a Presidential Commission to end 'the influence money has over our representatives in Washington', Adbusters endorsed forms of engagement with representative institutions that anarchists typically reject (Fuchs 2014: 20). Yet in Occupy camps, the social justice movements' anarchistic commitments to horizontalism, decentralisation, engagement and participation through consensus and opensource decision-making were common (Schrager and Lang/Levitsky 2012; Dowling et al. 2012; Shaw 2012; Husted 2015). Political languages that resonated strongly with anarchism were also used freely (Kaldor et al. 2012: 25; Pleyers 2012). Campaign materials put on the occupywallstreet.net website by activists in the NYC General Assembly injected explicitly anarchist commitments into ideas borrowed from the syndicalist labour union, the IWW. The response to the FAQ 'Who are your leaders?' was:

Occupy Wall Street is structured on anarchist organizing principles. This means there are no formal leaders and no formal hierarchy. Rather, the movement is full of people who lead by example. We are leader-full, and this makes us strong (http://occupywallstreet.net/learn). 
Not all Occupiers were anarchists, but the involvement of activists in camps already populated by activists familiar with, if not predisposed to anarchistic practices, gave Occupy an anarchist flavour. While there is considerable disagreement about the virtues of Occupy's anarchism, there is general agreement about the appropriateness of the 'small-a' anarchist designation (Kauffman 2011; 47-9; Mouffe 2013: 114-15; Dean 2013; Cornell 2013; Szolucha 2017: 8).

The selection of Occupy Wall Street, Occupy London St. Pauls and Occupy Oakland (indicated by OWS, LSX, and OO respectively) in our analysis was guided by our primary concern to explore the enactment of anarchist constitutional processes, not to present a comprehensive narrative of any single camp, still less document the politics of the movement as a whole. In this respect, Occupy Wall Street (17 September-15 November 2011), is crucial to our analysis because it constituted the movement. London St. Pauls (15 October 2011-28 February 2012) was one of the longest surviving camps and it produced a rich archive of documents. Occupy Oakland, or the Oakland Commune as it was also known (10 October-21 November 2011), gained a profile in the global movement after it successfully organised a strike in the Bay Area where 30,000 protesters shut down the Port Authority on 3 November. Repeated police raids, the extraordinary violence used to finally evict the camp, and the Decolonize Oakland movement we discuss below, also made Oakland a focal point for Occupiers across the world. Decolonize Oakland was a hugely significant constitutional moment in the brief history of the Occupy movement.

We have used a qualitative analysis of GA minutes of these three Occupy camps to examine their constitutional processes. GA minutes make up only part of the camps' archives (these also include, for example, statements of principle, consensus agreements, press releases, working group reports and camp journals). However, GA minutes importantly record the decisions that participants made as well as the discussions that led to them and thus provide the most reliable and comprehensive data on the functioning and purposes of the camps: They report facilitated discussion and decisionmaking processes and document feedback and formal reports from the working groups, committees and caucuses, variously set up or sanctioned by the GA. They also record the 'temperature' of the discussions - the collective mood of participants. GAs met regularly, anywhere from three times a week in Oakland, to three times a day in New York and London, when need arose. It is not possible for us to claim that GA minutes captured the views of all Occupiers or that the minutes expressed a homogeneous potion (see Halvorsen and Thorpe 2015 on the multiple politics of Occupy). Yet the minutes are an important primary source of evidence hitherto ignored, in spite of the fact that most camps went to great lengths and costs to 
archive this data online for posterity. As such, it is reasonable to treat them as the most important formal expressions of the camps' constitutional politics

Data collection involved downloading the available GA minutes from Occupy websites and manually coding specific passages of the text. The size of the archive varies and in each case was restricted to the minutes available during the formal existence of the camps (i.e., between their founding and their eviction): the 45 sets of GA minutes from Wall Street, totalling over 210,000 words; the 50-odd GAs held in London, amounting to just shy of 124,000 words; and 44 GAs, totalling 59,400 words, from Oakland. We used a predefined list of codes based on our starting point in anarchist and constitutional literature and in a sample of reflections on the three Occupy camps written by participants and published after the fact, supplementing these with emerging codes suggested by the minutes themselves (i.e., something not covered in our preliminary reading but appearing to be a key theme became a new code to be used in subsequent coding). Instead of using frequency or discourse analysis we followed broadly what Corbin and Strauss call 'systematic analysis': 'an incident in the data [is compared] to one recalled from experience or from the literature' (1998: 95). We also deployed the tools of contextual analysis in the history of political thought, interpreting meaning with reference to the discursive, political and social context of their utterances (Skinner 1969). The data was taken as the starting point for an inductive development of concepts that were brought into conversation with the relevant philosophical and theoretical literature (Peräkylä and Ruusuvuori 2011: 530; Seale 1998: 127-31).

\section{Real democracy and counter-power ${ }^{3}$}

The four key features of constitutional politics set out above are articulated and practised in the Occupy Wall Street movement. But what forms of power did the Occupy movement seek to constrain? The constitutional politics of Occupy Wall Street was an inspiringly ambitious attempt to

3 While not clearly defined, 'real democracy' is a term widely used in radical activist circles to distinguish the values of democracy from its institutionalisation. 'A real democracy ... is a direct and participatory democracy, in which all citizens have the possibility and the right to participate in the decisions that affect our lives and our communities. While the powers that be and mainstream media and pundits argue that such a citizen-based democracy is not possible or even desirable, there exist in fact a range of new institutions and experiments - as well as some old ones - that show that a direct and participatory democracy is both possible and feasible today. These democratic innovations, however scattered and limited, could, if improved, strengthened and spread, be tools for a radical democratisation of society' (Hansen 2013) Like Graeber (above), Hansen conflates democracy with constitutional politics as such. Our aim here is to distinguish the radical potential, and relative autonomy, of both. 
challenge and constrain the power of global capitalism, and the intersecting regimes of domination felt by dispossessed publics worldwide.

Occupy's constitutionalism began from the critique of capitalism, corporate control and the corruption of democracy, and signalled an intention to reset the principles of democratic power-management. The structures of power and injustices of corporate capitalism that catalysed the protests were at the forefront of most of the official documents: the Principles of Solidarity, The Declaration of The Occupation of New York City, the Decolonize Oakland manifesto, and others. As the Occupy Wall Street 'Statement of Solidarity' (POS) put it, the Occupation intended to resist the collusion between the banks and the state, and 'reclaim our mortgaged future' (POS 23/9/11). Wall Street was an obvious location for the protest and the 'Declaration of the Occupation of New York City' emphasised the significance of this choice, linking the hypercapitalism of Wall Street to ecological collapse, elitism, the military-industrial complex, racism and other forms of inequality and exploitation.

Each subsequent camp became a unique, spatially and sociologically distinct testing ground for integrating anarchist politics with non-anarchist communities and concern, responding to the ways in which global structures of power and domination manifested in those particular locales, from street drinking and homelessness, to white supremacy, foreclosures, student debt, colonialism, and the legacy of the transatlantic slave trade. Yet the vocal commitment to real democracy that Occupy articulated, in opposition to corporate and elite power, can be seen as a critique of global power as domination. As we will show below, this echoed throughout the camps' engagements with a whole range of oppressions which participants weighed differently.

On a local level, the practice of real democracy meant that Occupy camps embraced self-governance, pluralism and diversity. As one member of London Occupy put it: 'Democracy by definition has to be something in the making. The point where we start thinking of it as an idea that adheres to a particular form is when we lose it. It should be constantly evolving' (LSX 13/1/12). Real democracy committed Occupy to grass-roots activism and supported Occupy's anarchistic commitments to leaderlessness, transparency and dialogue, the disavowal of hierarchy, representation and elitism - both corporate and political. The rejection of domination and control was common in calls to democratic empowerment. Yet in embracing Occupy's glocalism, participants found different ways to express their resistance to power through real democracy. The Oakland Feminist Bloc rallied its supporters to the solidarity actions with striking dock workers by calling 'All women, transgender people, etc. come to the Feminist Bloc and march with us to the port. We are against capitalism, because under capitalism we suffer and are controlled' (OO 31/10/11). While the London 
camp's location in the heart of the city of London symbolised a movement rejection of corporate finance and corrupt banking interests, echoing the politics of OWS, its early eviction from land owned by the Corporation of London to Church grounds around St Paul's Cathedral, provided the camp with a particular historical narrative. The welcome extended to the occupiers by Giles Fraser, then Canon Chancellor of St. Paul's and formerly Rector of St. Mary's in Putney, was particularly influential in this respect, helping to forge a sense of continuity with London's republican past, notably with the seventeenth century Levellers and the Putney Debates (LSX 18 November 2011). Magna Carta was similarly invoked in London to invite participants to 'Re-discover your humanity, common sense, understand you are not agents of the government but human beings with a birth right' (LSX 7/12/11).

Real democracy was also operationalised to check known and hidden power structures within the camps. Occupy Oakland (also known as the Oakland Commune) (OO) was especially marked by the intensity of debates about power asymmetries resulting from intersections of race, colonialism, class and culture. The anti-capitalist, anti-white supremacist and antipatriarchal Croatoan collective characterised $\mathrm{OO}$ as the most racially and ethnically diverse Occupy encampment worldwide (Croatoan 2012). Whether or not this was actually the case, the legacy of the Atlantic slave trade, white settler colonialism, civil rights and the militant black activism of the Black Panthers were keenly felt from the outset. The killing of the 22-year-old African American Oscar Grant, shot in the back by Oakland transport police in 2011, was the headline event in the formation of the Oakland camp, leading to the renaming of Frank Ogawa Plaza - the site of the camp - Oscar Grant Plaza. Participants also expressed lasting solidarity with the Chochenyo Ohlone people, the indigenous inhabitants of the land, and both processes would ultimately lead to extensive auto critique and ultimately the Decolonize Oakland movement and the split that followed.

If members of $\mathrm{OO}$ were especially aware of the structures of power that shaped their interactions they were not the only Occupiers 'to check each other' (OO 23 October 2011) or demand that sexism and racism to be 'called out'. The London GA also reported that 'people are not being respected and being attacked' (LSX 13 December 2011) and recorded that the 'issue of Sexism and Racism in occupy needs to be addressed. Women and people of colour have experienced sexism and racism: being ignored, being bullied. As a result many have being [sic] leaving' (LSX 7 December 2011).

The intersectional politics of faith, race and ethnicity was treated as another node of hidden power. London organised an interfaith/no faith working group and a multi-faith tent. The GA reported that atheism was a barrier to 'British black people, Chinese etc. who are well organized, hard to penetrate and very religious' (LSX 6 January 2012). The commitment 
to non-violence, the celebration of Martin Luther King Day and the welcoming of Jesse Jackson to the camp on 15 December 2011 reflected the concerted effort to embrace faith communities. The same racial political intersection was active in Oakland (Liu 2012). Here, faith groups, from white, black and indigenous communities, participated in the GAs and led vigils and blessings. In a discussion on 24 October about how to develop the camps and build capacity, one participant noted: 'I am a person of faith. Faith community should be involved. Black churches were the backbone of the civil rights movement. All, believers and not, need to be involved, not just white anarchists. Talk to people in black churches and they think the protesters are all white, dirty, and on drugs. Draft a letter to churches and send to GA as a proposal.' (OO 24 October 2011)

This identification of dominating practices was part of a positive politics of affirmation. One 'woman [...], person of color and a queer person', made the point that society tends to shut people like her out and keep her silent. The GA 'is a place to speak!' (OO 24 October 2011). Participants in all three camps attempted to expose the power imbalances and institute modes of self-governance capable of combating them. Camps did not resolve the tensions arising from intersectionality and the global power asymmetries that participants wrestled with. As one participant noted on 9 November, 'White privilege informs the tactics used here, and we need to examine that. Some people can afford to employ any tactic and can afford to go to jail. Others are more vulnerable' (OO 9 November 2011). The recognition of these tensions was central to the practice of radical democracy, and it provided the dynamic which transformed the Occupy movement from an ideal, narrowly associated with a process of consensus decision-making, into a broader constitutional politics (Springer 2011b).

In sum, to constrain power, the Occupy camps adopted four constitutionalising practices. First, was the writing and distribution of constitutional documents and statements of principles. These called the occupations into being, set out the systemic forms of power and the regimes of domination they sought to challenge, and articulated the main cleavages to which the constitutional politics would be directed. Second, camps institutionalised, developing practical and sophisticated ways of balancing power in the locales, which also acted as embodied critiques of and counters to the ways in which the modern state and the institutions of global power institutionalised multiple forms of intersecting oppressions. Third, the Occupy camps had clear and effective rules, both de facto and de jure, underpinned by key commitments, in particular anarchy and its more common synonyms, such as horizontality, mutual aid, solidarity and so forth. It is these key principles, above all, that were mimicked globally. Finally, the democratic decision-making procedures of the Occupy camps 
were varied and plural, but sought to maximise participation, counter representational structures of political dispossession in mainstream politics, and give the people room to articulate their voice.

\section{$\mathrm{V}$. The anarchist constitutional politics of Occupy}

The sections below examine how Occupy adopted the four constitutional processes that we draw from Castiglione (above): declarative principles, institutional arrangements, rule-making processes and decision-making procedures. After sketching these processes we return to the theory of constitutionalism to explore the distinctiveness of its anarchist enactment in Occupy.

\section{(i) Declarations}

Occupy Wall Street was formally constituted through three key documents: the 'Principles of Solidarity', agreed on the 23/09/11, the 'Declaration of the Occupation of New York City' agreed by the GA a week later (29/09/11), and the 'Statement of Autonomy' (10/11/11), developed to coordinate external communication just a day or two before the coordinated evictions of all the camps. The Declaration set up OWS as a battle between 'them and us', the 99 per cent and the 1 per cent as it was later rebranded, while the initial Principles outlined what the group was for. While the former set out what Occupy was against - e.g., 'foreclosures', 'colonialism' and 'environmental degradation' - the latter promoted its enabling agenda:

Engaging in direct and transparent participatory democracy; Exercising personal and collective responsibility; Recognizing individuals' inherent privilege and the influence it has on all interactions; Empowering one another against all forms of oppression; Redefining how labor is valued; The sanctity of individual privacy; The belief that education is a human right ( $\operatorname{PoS} 23 / 09 / 11)$.

The Statement of Autonomy set out Occupy's principle of direct action: 'Occupy Wall Street is a people's movement. It is party-less, leaderless, by the people and for the people' (SoA 10/11/11). The oblique reference to the Gettysburg Address is significant, since over the preceding week, the GA minutes demonstrate that participants at Occupy had been linking its constitutional moment into US history. A constitution working group was established on 11 October and an Article V working group on 17 October. ${ }^{4}$

4 The remit of this group was to consider how OWS might use art V, which regulates constitutional amendments to the US constitution, to 'bypass the Congress' and revolutionise the US democratic process. 
The Principles of Solidarity and the Declaration of OWS are remarkable documents. Charging corporations with a substantial list of violations, the Declaration invoked the language of individual rights to constitute 'the people' through a shared identification of grievance and solidarity in protest, urging 'the people of the world' to 'assert your power' (OWS, 29 September 2011). The New York Assembly explicitly presented the Declaration as a statement of resistance that others could adapt. Reminiscent of the hallmarks of Peoples' Global Action, the Declaration constituted Occupy as a movement through subscription to the Declaration's broad aims and encouraged plural groups to constitute under the banner of Occupy through independent local protest (PGA, 1999/2001). In London, the process not only involved participants organising in working groups to discuss and decide the camp's aims (LSX 17 October 2011), it also resulted in a ten-point Initial Statement that was agreed as 'a work in progress and used as a basis for further discussion and debate' (LSX 26 October 2011).

The liquidity of London's declarative statement was sustained by the continual development and restatement of principles, notably in the Corporations Statement (LSX 25 November 2011), The Economics Statement (LSX 6 December 2011), and the Statement of Autonomy (LSX 14 December 2011). These all fleshed out the camp's principal commitments and values. The rejection of the statement of autonomy produced in Glasgow as an inappropriate model, 'more like a constitution' than participants in St. Paul's were prepared to stomach, perfectly encapsulated the flexibility of the constitutional process to local political sensibilities (LSX 13 December 2011).

Disquiet about the language of the Declaration of the Occupation of New York affirmed its foundational status and also the balance of popular over elite power. Protests stimulated by the intersectional politics of the camps were expressed as early as 3 October at the New York GA: 'I'm a member of the people of color working group. Right now we are working on bringing more people of color participation for people who don't relate to occupying because this base has been occupying sense [sic] 1492 and people of color labor have been exploited sense [sic] the beginning of time. So we don't want to recolonize that occupy' (OWS 3/10/11). This charge that Occupy had failed to engage with its own colonial legacy came to a head at Oakland when the proposal to change the name of Occupy Oakland to Decolonise Oakland was posted online the 3 December, 2011, shortly after the second eviction of the camp.

The Decolonize Oakland controversy is the most powerful example of the deployment of non-domination as a tool to reconstitute Occupy's core norms in a more anarchistic form. Discussed at the OO GA on the afternoon of 4 December by approximately 350 participants, the proposal 'Decolonize 
Oakland: Creating a More Radical Movement' built on the OO 'Memorandum of Solidarity with Indigenous Peoples', which had been passed by the GA with 98 per cent support on the 28 October. It opened as a statement of solidarity with the Chochenyo Ohlone people, the original residents of the Oakland area who had 'survived a brutal colonial history and ongoing occupation' of their ancestral lands. Proponents of the proposal argued that decolonising Oakland would entail a root-and-branch reform of the colonial tendencies in the Occupy movement, most obviously its choice of moniker. As one participant put it: 'The history of Wall Street is built on the colonization of the indigenous people, and the slavery of Africans on the land. The seats of power are within us - we do not need to use the same paradigm of "taking seats of power".' (OO 4 December 2011) Further, the language of occupy was tainted by associations with the occupations of 'Iraq, Palestine and Afghanistan', and it evoked the colonising tendencies of 'corporate capitalism', through the socio-economic means of 'foreclosures', 'gentrification', 'segregation', 'police occupation', and (following the evictions from the Oscar Grant Plaza), the appropriation of public lands. To occupy 'echoes' and 'normalizes', 'colonialism under a new name'. The authors of the proposal recognised the achievements of OO, but also pointed out where the Commune could push further:

The divisions that exist between the $99 \%$ and the $1 \%$ are built on colonial relations. It is our lands, our labor, our bodies, and our voices that have been stolen; at the encampment at Ogawa/Grant Plaza and in our local neighborhoods, we have come together to decolonize our minds, restructure our relationships to one another, and build political institutions that meet the needs of all people. What we are doing is decolonizing Oakland. Let us choose a name that reflects our actions and beliefs. Decolonize Oakland! Liberate our communities! Practice freedom! (Decolonize Oakland proposal 2011).

The language of occupation perpetrated violence and extended Oakland's colonial legacy. Not wanting 'to fly on the coattails [sic] of imperialism', decolonisers argued that the issue was 'not just about indigenous people. It's about recognizing the history of the shoulders we stand on.' Against objectors who worried that the name change would dent Oakland's internationalism, advocates argued that people would still see that the camp was part of "the global movement, just like the "Arab Spring" or "Los Indignados"'. The proposal 'pushed the envelope of this conversation' and made some GA members 'uncomfortable'. But others felt far greater discomfort because they had to wrestle with the everyday oppression of colonial thinking. One commented: 'welcome to my world. This emergency has been on hold for over 500 years. We are more than a brand' (OO 4 
December 2011). ${ }^{5}$ Decolonize Oakland thus explicitly re-articulated the radical politics of the Oakland struggle and reframed the OWS declaration by redefining who 'the people' was (see also Some Oakland Antagonists, 2012: 410).

\section{(ii) Institutions}

Occupy camps established and managed governance, welfare and cultural institutions through working groups, committees and spokes councils. These included decision-making and media bodies, kitchens and educational facilities (lecture spaces, libraries, the London Tent University), outreach organisations and prayer rooms. Camps produced online and print materials, organised teams to address anti-social behaviours, managed finance and budgets (often dealing with huge sums of money), negotiated with external bodies, organised the physical spaces and the hygiene and sanitary arrangements and also attempted to provide for significant numbers of street homeless, many of whom had complex needs and who flooded into the camps seeking company and care. Faced with the eviction from St. Pauls, the London camp set up a working group to organise support for vulnerable people, transport and storage of physical items (LSX 15 December 2012). The 'category 1 stuff' - 'items that could be used for future occupations' - included 'four solar panels, books and files' and the contents of the 'tech tent' (LSX 24 January 2012).

The commitment to horizontality or, as the OWS Principles of Solidarity put it, 'questioning hierarchy' (OWS 10 November 2011), underpinned the institutionalisation of camp norms. For example, the Tranquillity teams established to address anti-social behaviour were charged with conflict resolution and mediation not rule-enforcement. Their remit was to find mutually accommodating solutions to problems; judgment and penalty was left to the GAs.

As the primary decision-making body in all three camps the GAs also attempted to institutionalise non-domination, relying on facilitation to do so. Recognising that the facilitators were hugely important individuals in the camps, OWS GAs often began with a statement similar to this one made on 29 November: 'Facilitation is a process of shared power. They are not leaders. Everybody has the right to be a facilitator.'

Governance arrangements were revised as camp institutions proliferated over time. The OWS GA acknowledged the difficulty of providing effective

5 Other camps were similarly uncomfortable with the 'Occupy' label. In Victoria the name 'Occupy' was rejected because of the colonial connotation of the word. It was formally renamed the People's Assembly of Victoria (POVA), and continues to function under this name as a mailing list and website (https://www.paov.ca/) for activism in the city. Thanks to Simon Springer for drawing our attention to this. 
oversight, coordination and communication between nearly 70 'chartered' working groups and caucuses towards the end of October. A Facilitation Working Group was proposed on 25 October to coordinate and publicise proposals, facilitate the GA and maintain the ethos of consensus decisionmaking. A week earlier, on the 21 October, a separate proposal was put to the GA to set up a Spokes Council, using a model widely adopted in the alter-globalisation movement (Maeckelberg 2009, 2011, 2013; Graeber 2008). Institutional changes were only agreed when the GA was confident that Occupy norms would be preserved. Arguments about the introduction of the Spokes Council, which arranged working groups around a central hub like spokes on a bicycle wheel, turned on this issue. One contributor to the GA stated: 'this spokes council model is not a hierarchy. It decentralizes power. It gives power to working groups and caucuses. It would never supersede the GA. It does different work than the GA. The spoke council would deal with logistical and financial decisions, whereas the GA would deal with larger political questions about OWS and the greater movement.' (OWS 21 October 2011) Still, some worried that the SC would 'take [...] power away from the GA' (OWS 28 October 2011). To break the impasse, one speaker at the GA invoked the 'guiding principles of solidarity', and their benchmarking for distributions of power, while another made clear that 'The principles of solidarity are always being added to by the GA, it's a living document so as the GA continues to change so does the SC.' (OWS 28 October 2011).

Disagreements were less easily settled when participants contested the meaning of institutional norms. The establishment of a Mayor of London working group to stand a protest candidate at the London mayoral election proved particularly contentious, (LSX 25 January 2012). Moreover, not all institutions were actually controlled by the GAs. In London, one of the disputes between St. Paul's and the sister camp, the Bank of Ideas, revolved around access to the passwords for social media accounts and to the London Occupy website (LSX 16 December 2011). Yet where institutional failures were identified, GAs invoked norms to exercise constraint. The London GA referred to the general commitment to non-representational politics to call out groups or individuals who used the name of Occupy without having secured explicit agreement of the GA, and, in the case of the proposal to run an Occupy Mayor candidate, pointed to the non-party political principles outlined in the Initial Statement to dispute the proposal. The GA similarly appealed to principle to encourage working groups to address dwindling participation in agenda-setting meetings (LSX 24 November 2011). In other cases, GAs revised processes to correct for institutional failures. For example, rewards and rotas were discussed as a way to increase participation in London's information working group (LSX 24 November 2011). 
A similar mix of normative appeals and institutional processes were used to control perceived abuses of power. To put a stop to late-night partying and contraventions of the prohibition on alcohol and drugs at St. Paul's, the London GA agreed to remove empty tents and downsize the camp (LSX 28 January 2012). Recurrent discussions of the necessary institutional checks on power did not always result in consensus, but proposals included the introduction of a fractional rotational membership of the Church Liaison working group to balance the need for continuity in negotiation against the risks of petrification. Institutional innovations also included revisions to the GA meeting times to facilitate attendance, and rotation of GAs to foster inter-camp co-operation. Financial institutions included the introduction of authorised spending caps to limit and monitor routine camp expenditure, and accounting policies to ensure financial accountability and transparency (LSX 1 December 2011).

In Oakland, the GA was an institution primus inter pares, but the Facilitation Committee was perhaps the central body for deciding how that worked. On the 9 November, minutes state that 'Facilitators have the discretion to structure the process as needed based on the type of proposal that is on the table, the general attitudes of the assembly, and the number of attendants at the GA.' In practice, this meant facilitating general assemblies with between 200-900 regularly voting at Oscar Grant Plaza. The high point was the 26 October, where the GA discussed the general strike and port shutdown, which attracted 1500 active voters.

There were 30 committees and caucuses listed on the website and many more that emerged organically and on an ad hoc basis. There was an anarchist caucus meeting regularly by the end of the camp's life. These committees ran everything from camp security, homelessness, facilitation, finance, gardening, to the kitchens. The caucuses coordinated activities for intersectional groups too: feminists, people of colour and queer people of colour. Committees were established to challenge power imbalances within the camp as well as manage the affairs of the camp. They were not simply bureaucracies, though they performed important aspects of this role, but they were also self-defence communities. For example, the Women/Trans/Queer Caucus institutionalised the campaign against sexism in the camps (OO 23 October 2011), while the Safer Spaces committee worked 'to address issues of trauma and oppression within the movement, towards the goals of increased participant sustainability and collective liberation' (https://occupyoakland.org/getinvolved/). On 24 October, so within a week or so of the camp's establishment, the Safer Spaces teams were developing processes and procedures, looking to 'implement policies and interventions that we all agree upon' (OO 24 October 2011). 
There were proposals at Oakland to establish further affinity groups, and others to take the skills learnt in the camps to neighbouring communities. On the 4 November a Community Democracy Neighbourhood Project was proposed to create neighbourhood assemblies, mirroring those in Spain, Greece and Egypt, while on 9 November the Occupy Oakland Plugin Committee was proposed, encouraging Occupiers to get more involved in local initiatives and campaigns. An attempt to establish a spokes council to manage the interrelationship of the groups, modelled explicitly on the OWS system, was proposed on 11 November three days before nationallycoordinated police raids evicted all the camps in the US.

\section{(iii) Rules}

The importance attached to the institutionalisation of norms meant that the constitutional documents ratified by GA were not replete with stipulations detailing the relationship of the various institutions to one another, nor the rules members ought to follow. In answer to the question, 'What is a working group?' a facilitator at the London GA replied: 'When there is a need, a working group can be set up to address it' (LSX 3 December 2011). Nevertheless, camps had rules, for example regulating fire safety, finances and the media. Some rules, about the use of consensus decision-making for instance, seemed to be adopted as assumed norms. Others were agreed during the period of the encampments. In London rules about the physical site were made pragmatically with a view to defending the camp against the threat of instant eviction. Others emerged from conflicts, transgressions and the need to balance the expectations, values and aims of sub-groups within the camps. One facilitator at London observed: 'Half the people in camp want to be here to party, half want to be activists, half the people want to care for people, half the people want to be here for the politics' (LSX 9 December 2011). While widely shared commitments to equality, respect, dignity, mutual aid and direct action generated highly regulative normative order, the pursuit of the virtues through the practices and institutions of Occupy camps also generated tensions which rule mediated.

To assume rule-making and observance was voluntary would be misleading. Take cooking and cleaning for example, as one occupier put it at an early GA in New York: 'If you're here, I expect you to clean. As I said earlier, it's not a mandate, but it's not an option.' (OWS 13/10/11) Combating sexist behaviours - catcalling, groping, sexual harassment and abuse - produced mandatory policy. The OWS GA began to discuss and formulate safer spaces policies from the 27 September. The eventual policy was designed to resist 'oppression' and to be aware of 'privilege', to be 'respectful' to ensure that all occupiers treated each other with dignity (OWS 29 September 2011). 
The relationship of rules to the institutional form of the camps was also discussed at OWS, particularly in relation to the Spokes Council proposals (OWS 21 October 2011), the drumming circle 'Pulse' (OWS 24 October 2011) and rogue working groups (OWS 28 October 2011). The Principles of Solidarity were used to benchmark group and individual behaviours. The GA was expected to rule on infringements of camp norms and had the right to 'decharter' groups and disavow statements made falsely on behalf of OWS. Groups like Pulse were also expected to regulate themselves. Where self-regulation failed, OWS had a Peace Council, which developed mediation and reconciliation processes much like the London Tranquility teams (OWS 25 November 2011).

One of the earliest formal regulations to be passed by the Oakland GA regarded external communication. On the 31 October a proposal passed to ensure external communication went through the GA or it would be disowned by OO. A second was about finance. There were no by-laws or specific regulations for managing money, yet on 26 October an announcement was made that OWS had donated $\$ 20,000$ to OO and, by 7 November, OO had raised $\$ 7500$ through online donations. Because there was so little formal process to manage finance, the cheque was not deposited into the Wells Fargo account until the 9 November. By 11 November, the extent of the influx of donations and supplies prompted a proposal to develop transparency and accountability through the establishment of a spokes council on the OWS model, and even offer microfinance loans to the local community. Eviction prevented this, but the emergence of rules and institutions from the demands of context, and in the spirit of OWS should not be overlooked.

In London, rules were introduced to regulate institutions, address behavioural problems, enforce compliance with GA policy and, importantly, to stave off the early threat of eviction. Finance rules were reworked by the GA at the start of December to ensure transparency and effective camp accounting (LSX 1 December 2011). Security was another dominant concern. The security discussion at the GA on 3 December reported: 'Alcohol and drugs use on the rise in the camp. Use of violent words and behaviour, threatening language makes this an unsafe camp especially for women. Several outstanding incidents occurred such as one female who had a drunk come into her tent. Also raise the issue of dogs urinating all over camp and dog fights' (LSX 3 December 2011). A Safer Spaces policy was introduced and, following complaints about the moderation of the livestream, a separate Online Safer Spaces policy. In an effort to project a good public image in the courts, the London GA adopted a charter which committed all Occupiers to keeping the camp clean and tidy and restricted the operating hours of the kitchen. The Core Ground Rules for Camp Members, adopted 15 December 2011, required 
peaceful, non-violent, sober, process/GA-respecting behaviour. Anyone behaving in ways which violate these core ground rules can be asked to leave the camp. The camp can dissociate from individuals who repeatedly violate; they will no longer be considered as members of the camp and will not be welcome to access camp facilities or to be involved in decision making.

While the London GA also discussed involving the police to deal with persistent camp violence, ostracism remained the principal means of sanctioning, either from the camp or from specific decision-making process. Moral judgments were implicit in some of the debates about 'drunks' and threat of exclusion placed a high premium on compliance within the camp sub-culture.

\section{(iv) Decision-making}

It is difficult to overestimate the constitutional weight that attached to the consensus decision-making (CDM) processes the camps adopted. More than anything else, this symbolised the alternative to the corporate corruption of representative institutions and the commitment to an alternative based on participation, deliberation and inclusivity. The GAs became the primary institutions in the camps because they embodied this 'real democracy'. The inaugural London GA held on 9 October on Westminster Bridge, just prior to the establishment of the St. Paul's camp states:

The General Assembly is the main decision-making forum for \#occupylsx - as it has been for other international occupations, drawing on the model pioneered in Spain earlier this year. It's a form of direct democracy, a space for debate that is totally open to the public - it's there for anyone who wishes to make their voice heard and there is plenty of room for dissenting voices, although we try to reach consensus.

Mimicking the pre-existing methods of other and previous global anarchist movements, CDM was an integral part of an educative process designed to build solidarity and undo the competitive, self-interested cultures fostered by electoral politics and party-political competition (for more see Maeckelberg 2009). In order to maximise participation and disseminate norms of respectful disagreement, the procedures, which relied on hand signals - 'jazz hands' - were routinely explained at length by facilitators in all the camps at the start of every GA. Considerable time was taken to explain the appropriate use of the block too - the veto that every participant has to reject proposals and proceedings if core values are thought to be at stake - to help participants break with voting habits based on the expression of individual preference. In London, worries that GA members were using 
blocks inappropriately, simply to express disagreement, led one participant to complain 'Blocks are for when someone fundamentally opposed. There's a problem because people are blocking when it's not time to block' (LSX 1 November 2011). But as Mark Bray has observed, without consensus decision-making, it is likely that the anarchistic ethos of the camps would have been voted out of practice very quickly (Bray, personal communication). Consensus decision-making, as we discuss further below, was deeply conservative, for better and worse.

Dialogue was an essential part of the consensus process. In order to foster engagement, GA participants often subdivided into smaller groups both to discuss proposals and/or vote within groups, tallying totals centrally to arrive at the final decision. London participants complained when the GA was run 'in an aggressive, militaristic, alpha male, unfriendly way' or when considerations of efficiency appeared to outweigh issues of deliberation. At the same November GA one member observed: 'This conversation is the most useful of all those in GA's yet. Some say "we have to rush" - no, we do not have to rush. There's a difference between deciding to have talks about talks, and agreeing about the way we have those talks. We make the decision about how we have those talks, and we do that in our own time.' (LSX 1 November 2011). And although some decisions were taken by a small number of GA participants especially on cold nights in London - and with high rate of abstention, decisions were often postponed in order to allow more time for GAs to arrive at genuine agreement. The practices 'arrived at through experience and experimentation' during the life of the St. Paul's camp were also published on the Occupy website.

While all camps attested to building consensus and giving everyone a veto, OWS and $\mathrm{OO}$ introduced modified consensus decision-making (MCDM), usually demanding a threshold of 90 per cent plus majority. In OWS, MCDM was used in the Spokes Council as well as in the GA. OO took a decision to adopt modified consensus or supermajorities early on, though the precise threshold was not listed in the minutes. One of the high points of OO democracy was the passing of the proposal on 26 October for a 'General Strike: We propose that people walk out of schools and jobs, and converge downtown to shut down the city on November 2, 2011.' This was passed by the largest number of participants with an incredibly high majority: 1,484 to 36, with 77 abstentions - a supermajority of 96 per cent.

However, the use of MCDM was not problem-free. Requiring supermajorities meant that proposals that gathered 65 per cent plus of the vote routinely fell. On the 23 October a proposal to the OO GA entitled 'Friendly Neighbor Policy: Zero tolerance for racism, sexism, harassment, violence. Be respectful of all people and visitors. Let our revolutionaries sleep 
between 12 am and 9am', fell despite a 63 per cent majority, and a large proportion of abstentions. Most significantly, the Decolonize Oakland proposal fell with 68.5 per cent of the vote (198 voted for, 19 abstained and 91 voted no), resulting in the ignominious division of the camp.

Decision-making processes structurally constituted the Occupy camps. As Halvorsen and Thorpe (2015: 103) note, London Occupiers became increasingly disenchanted with the decision-making processes of the GA as debate spawned anger and conflict. Elsewhere, too, the experience of CDM was often disempowering. Debates about the Decolonise Oakland proposal rumbled on for days on web forums. Yet it was widely accepted that the process and proposal had generated an important discussion that would not have been had without it. If, as Nathan Schneider remarks, the decision-making procedures of the Occupy Wall Street were initially offputting for a lot of people, within weeks of the establishment of Wall Street, over 700 such camps had popped up across the world, each adopting the same methods. Having come to the camps expecting to be frustrated by the anarchists' insistence on 'process', Schnieder notes that '[a] lot of newly politicized people were suddenly feeling anarcho-curious' (Schneider 2013: 75). From our perspective, the significance of CDM was that it moulded Occupy as a democratic protest against power as well as a constitutional experiment to constrain it.

\section{Conclusions}

The minutes of the three Occupy camps we have analysed show us that anarchist constitutional politics is alive and kicking, but that it is not without its own internal contradictions. The constitutional politics of the Occupy movement was a positive response to the failures of global capitalism since 2008, and associated with global protest movements sharing similar concerns. 'Building the new in the shell of the old', the camps sought to show that 'another world is possible'. Finding the state and global capitalism to be part of the problem rather than the solution, these activists constituted alternative sites of political agency in ways that echo and drew inspiration from events as diverse as the Putney Debates, Gettysburg, the Paris Commune, the Arab Uprisings, the Indignados and the $15 \mathrm{M}$ movement. Occupy constitutionalised in four ways, each echoing the past, but did so innovatively and with specific contemporary needs in mind. The declarative statements, foundational texts and principles of solidarity called the community into being. The camps developed their own internal rules both to organise and to distinguish the camps from the mainstream modus operandi. The camps pluralised internally, and reached out beyond the confines of the spaces they occupied. This emergent 
institutionalising process enabled each camp to identify with the whole movement and carve out its own unique identity. Finally, Occupy adopted decision-making procedures that would enable and empower the participants, preferring consensus and supermajorities to the corporate lobbying and simple majoritarianism of contemporary liberal democracy.

By constituting themselves as sites of protest and lived transformation, Occupy immediately confronted the internal and external contradictions these constitutional innovations produced. Decolonize Oakland is the most spectacular and instructive example of this, but camps everywhere found they had to balance commitments to full participation and inclusivity against all manner of internal and external pressures. Their attempts to resolve this were complex and imperfect, even while they were collective and affirming.

What can we learn about anarchist constitutional politics from the analysis of Occupy? And what can we take from this for constitutional politics on the left more generally? The major lesson extends from the priority the camps attached to constituent power and the primary concern to resist domination. In both respects, the Occupy camps adopted positions that dovetail with - if not extend from - historical anarchist traditions. On the one hand, mirroring republican calls to balance power, the repeated call was to 'CHECK YOURSELF!' (OWS 28 September 2011). The rejection of representative politics was part of this. On the other, real democracy was identified with CDM, yet the results of Occupy's re-conception of power, and the plural institutions they built to balance and constrain it, also produced constitutional conflict and contradiction. Occupy managed power anarchistically by maintaining this tension or antinomy between articulating the democratic voice and balancing power, refusing a final point of authority in practice (Proudhon 1870). For example, there was no fixed arrangement for governance, and Occupy's foundational documents were described as works in progress. While the GA was considered the only body that could determine camp policy (in London it was routinely described as sovereign), its authoritative decisions functioned alongside and were constrained by the other camp institutions - normative and physical. Members of the GA were also members of the working groups, spokes councils and caucuses; the overlaps sparked debate about the entrenchment of power, but the cross-cutting plurality of the governance systems was generally embraced. Some rules were formalised, others were kept informal but they were typically practice-based and kept open to revision.

The failure to engage with constitutional questions head on, compounded by the absence of an anarchistic language for this, left the Occupiers without the conceptual toolkit to deal with the pressures active in the camps. Occupy shows us, and Decolonize Oakland in particular, that constituent and constituted power are always in dynamic tension. The refusal to fix 
this is what should mark an anarchist politics, and CDM and supermajorities are inadequate substitutes for a clearly thought through constitutional process that constrains or enables either.

Hardt and Negri are wrong to argue that the left is 'leaderless' and lacks a constitutional politics for a post-sovereign future. Our analysis shows that the left has a constitutional politics that comes from the anarchists, who take us beyond the liberal and republican paradigm of constitutional politics, in which the proper distribution of rights and powers, at some present or future point, will resolve the problem of constraint and empowerment. This constitutional politics has democracy at its heart, and makes constitutionalising fundamentally dynamic and open.

Occupy raises questions about robustness and viability. The traditional critique, one which Leninists like Hardt and Negri are also trying to work through, is about internal degeneration and susceptibility to the 'iron law of oligarchy' (Michels 1966 [1911]). The Occupy camps were not given the time to put Michels' arguments about the tendency to elitism to the test. Yet the camps give us cause us to re-examine Michels's critique, especially the claim that anarchism has simply been outpaced by modernisation.

The modernisation thesis presupposes that the constitutional form must meet the demands of power created by states: anarchist constitutions may work in their own terms, but they cannot be scaled up. Our analysis of the practices of the Occupy movement opens up a different possibility. Namely that constitutionalism points towards mimicry, 'linking across' as a protofederal practice, firmly within the tradition of anarchist constitutionalising. Occupy's spread and mimicry, from the adoption of the Principles of Solidarity, to the adoption of the GA and CDM, to the general anarchist ethos at the heart of the movement, underpinned a politics that supported unique camps in specific locales. Occupiers mimicked the occupation of public spaces by camping in them, and adopted the practice of CDM in general assemblies. A fuller appreciation of the camps' constitutional politics, beyond the GA, allows us to see how a whole raft of more subtle but equally effective practices capable of informing radical politics in everyday life, outside the camp, can be replicated in the same way. Occupy offered us a fluid structural form for thinking about constitutionalising in the absence/presence of a nation state.

The fixation on the demands and the specific form of the Occupations themselves, in particular the camp, meant many missed the anarchist constitutional politics that underpinned it. Yet the occupations refocus our attention on the transformative aspect of constitutional politics. The Occupy movement was flawed in this regard, as all political movements that respond to the transformed conditions of their own (re)production will be. But Occupy continued a long tradition of anarchist constitutionalising, which contains the hallmarks of its mainstream counterparts, albeit 
articulated in a new political context. The processes the camps adopted were constitutional in so far as they challenged, checked, balanced and regulated intersecting regimes of global/local power and domination. This approach to constitutionalising was anarchist insofar as the processes were structured by a broad commitment to anti-state and anti-capitalist nondomination, manifest in explicit adherence to real democracy and principles of horizontality, solidarity, mutual aid, and leaderlessness/leaderfulness.

This analysis of Occupy and the mimicry of anarchist constitutional politics illustrates for the first time how anarchist norms and practices generate complex constitutional practices. We have shown elsewhere how anarchist accounts of non-domination resonate and develop contemporary constitutional political theory, but more work awaits. How, for example, can anarchist constitutional politics help us respond to questions of the provision of social goods in mass societies, how does an anarchist constitutional politics respond effectively to problems of state violence or help us think differently about using and delegitimising violence? These and other questions demand more serious attention and our hope is that such a conversation is opened by our findings here.

Rather than abandon the language of constitutionalism, we can recuperate it from the mainstream and give it a new lease of life. Anarchist constitutional practices point to a new language of constitutionalism that moves from the sovereign 'I', in order to develop multiple and overlapping constitutional process for articulating plural 'we's' (Prichard 2017). It does so in order to challenge the iniquities of global power, in the micro-everyday locations of their intersection. Above all, Occupy shows us that we must resist the urge to think in terms of 'scaling up', and rather think in terms of linking across, imitating, multiplying and hybridising anarchy, constitutionalising the lived autonomy of communes, workplaces, villages, schools, in cities and across regions, as a dynamic constitutional politics of non-domination.

\section{Acknowledgements}

Research for this article was undertaken as part of the project 'Anarchy as a Constitutional Principle: Constitutionalising in Anarchist Politics' funded by the ESRC Transformative Research Award ES/N006860/1. The empirical data for this paper has been archived with Loughborough University and can be accessed at: <https://repository.lboro.ac.uk/articles/Anarchy_as_ Constitutional_Principle_Constitutionalising_in_Anarchist_Politics_ Occupy_data/7976435/1>. The authors wish to thank Mark Bray, Dario Castiglione, Elizabeth Frazer, Marisa Holmes, Harry Gould, Tony Lang, Andy Schaap, Simon Springer, Simon Thorpe, Mathijs van de Sande, Nathan Tamblyn and Stuart White for comments on the various drafts of 
this article. We would also like to thank participants at the following conferences and seminars for their valuable input: Political Studies Association annual conference, Glasgow 2017; the Oxford Political Theory Research Seminar, 2017; International Studies Association annual convention, San Francisco 2018; the University of Exeter Law School Research Seminar, 2018.

\section{References}

Adi, A. 2015. "Occupy PR: An Analysis of Online Media Communications of Occupy Wall Street and Occupy London." Public Relations Review 41:508-14.

Arenas, Iván. 2014. "Assembling the Multitude: Material Geographies of Social movements from Oaxaca to Occupy.” Environment and Planning D: Society and Space 32:433-49.

Bakunin, Michael. 1972 [1895]. Oeuvres Tome 1. Fédéralisme, Socialisme et Antithéologisme. Paris : P.V. Stock.

Bantman, Constance and David Berry. 2010. New Perspectives on Anarchism, Labour and Syndicalism: The Individual, the National and the Transnational. Newcastle-on-Tyne: Cambridge Scholars Press.

Bassett, Keith. 2014. "Rancière, Politics, and the Occupy Movement." Environment and Planning D: Society and Space 32:886-901.

Bellamy, Richard and Dario Castiglione. 2013. "Three Models of Democracy, Political Community and Representation in the EU.” Journal of European Public Policy 20:206-23.

Berneri, Camillo. 1942. Peter Kropotkin: His Federalist Ideas. London: Freedom Press.

Bohman, James. 2007. Democracy across Borders. Cambridge, MA: MIT Press.

Bookchin, Murray. 1993. "The Ghost of Anarcho-Syndicalism.” Anarchist Studies 1:3-23.

Bookchin, Murray. 1995. "The Left that Was: A Personal Reflection.” In Social Anarchism or Lifestyle Anarchism: An Unbridgeable Chasm, by Murray Bookchin, 61-86. Edinburgh and Oakland, CA: AK Press.

Bray, Mark. 2013. Translating Anarchy: The Anarchism of Occupy Wall Street. Winchester: Zero Books.

Brown, Garrett Wallace. 2012. "The Constitutionalization of What?” Global Constitutionalism $1: 201-28$.

Cagiao y Conde, Jorge. 2011. "Démocratie et théorie du droit fédératif chez Proudhon et Kelsen.” In Proudhon, Droit ou Morale?, edited by Anne-Sophie Chambost, 82-113. Paris: Centre National du Livre, Editions Société Proudhon.

Castiglione, Dario. 1996. “The Political Theory of the Constitution.” Political Studies, XLIV:417-35.

Chambost, Anne-Sophie. 2004. Proudhon et la norme: Pensée juridique d'un anarchiste. Rennes: Presses universitaires de Rennes.

Corbin, Juliette and Anselm Strauss. 1998. Basics of Qualitative Research: Techniques and Procedures for Developing Grounded Theory (2nd edn). London: Sage.

Cornell, Andrew. 2013. "Occupy Wall Street and Consensus Decision Making: Historicizing the Preoccupation with Process." In Is This What Democracy Looks Like?, edited by Cristina Beltrán, AJ Bauer, Rana Jaleel and Andrew Ross. Available at: <https://whatdemocracy-looks-like.org/introduction-is-this-what-democracy-looks-like/>.

Costanza-Chock, Sasha. 2012. "Mic Check! Media Cultures and the Occupy Movement." Social Movement Studies 11:375-85.

Croatoan. 2012. Who Is Oakland: Anti-Oppression Activism, the Politics of Safety, and State Co-optation. Available at: <https://escalatingidentity.wordpress.com/2012/04/30/whois-oakland-anti-oppression-politics-decolonization-and-the-state/>. 
De Laforcade, Geoffroy. 2010. "Straddling the Nation and the Working World: Anarchism and Syndicalism on the Docks and Rivers of Argentina, 1900-1930." In Anarchism and Syndicalism in the Colonial and Postcolonial World, 1870-1940, edited by Stephen Hirsch and Lucien van der Walt, 321-62. Leiden: Brill.

Dean, Jodi. 2013. "Occupy Wall Street: After the Anarchist Moment." Socialist Register 49:52-62.

Dean, Jodi. 2016. Crowds and Party: How Do Mass Movements Become an Organised Activist Collective? London: Verso.

Dowling, Emma, Anna Feigenbaum, Susan Pell and Katherine Stanley. 2012. "Occupy London." South Atlantic Quarterly 111:608-15.

Engländer, Sigmund. 2015 [1873]. The Abolition of the State: An Historical and Critical Sketch of the Parties Advocating Direct Government, a Federal Republic or Individualism. London: Forgotten Books.

Epstein, Barbara. 2001. "Anarchism and the Anti-globalization Movement." Monthly Review 53:1-14.

Fuchs, Christian. 2014. Occupy Media! The Occupy Movement and Social Media in Crisis Capitalism. Winchester: Zero Books.

Gerbaudo, Paolo. 2017. The Mask and the Flag: Populism, Citizenism and Global Protest. London: Hurst.

Gill, Stephen and A Claire Cutler (eds). 2015. New Constitutionalism and World Order. Cambridge: Cambridge University Press.

Goldman, Emma. 1892 [1979]. "What We Did about the Slaughter at Homestead." In Red Emma Speaks, edited by Alix Kates Shulman, 234-47. London: Wildwood House.

Goodin, Robert E. 2006. "Designing Constitutions: the Political Constitution of a Mixed Commonwealth." Political Studies XLIV 635-46.

Gordon, Uri. 2008. Anarchy Alive! Anti-Authoritarian Politics from Practice to Theory. London: Pluto Press.

Graeber, David. 2008. Direct Action: An Ethnography. Oakland, CA. AK Press.

Graeber, David. 2013. The Democracy Project: A History, a Crisis, a Movement. New York, NY. Spiegel and Grau.

Halvorsen, Sam. 2012. "Beyond the Network? Occupy London and the Global Movement." Social Movement Studies 11:427-33.

Halvorsen, Sam. 2014. "Taking Space: Moments of Rupture and Everyday Life in Occupy London." Antipode 47:401-17.

Halvorsen, Sam. 2015. "Encountering Occupy London: Boundary Making and the Territoriality of Urban Activism." Environment and Planning D: Society and Space 33:314-30.

Halvorsen, Sam and Simon Thorpe. 2015. "Occupying Power: Strategies for Change in Occupy London." In Waves of Social Movement Mobilizations in the Twenty-First Century: Challenges to the Neo-Liberal World Order and Democracy, edited by Nahide Konak and Rasim Özgür Dönmez, 101-14. Lanham, MD: Lexington Books.

Hammond, John. 2015. "The Anarchism of Occupy Wall Street." Science and Society 79:288-313.

Hansen, Camilla. 2013. "What Would Read Democracy Look Like?” New Compass. Available at: <http://new-compass.net/articles/what-would-real-democracy-look>.

Hardt, Michael and Antonio Negri. 2000. Empire. Cambridge, MA: Harvard University Press. Hardt, Michael and Antonio Negri. 2009. Commonwealth. Cambridge, MA: Belknap Press.

Hardt, Michael and Antonio Negri. 2017. Assembly. Oxford: Oxford University Press.

Hirsch, Stephen and Lucien van der Walt. 2010. "Final Reflections: The Vicissitudes of Anarchist and Syndicalist Trajectories, 1940 to the Present." In Anarchism and Syndicalism in the Colonial and Postcolonial World, 1870-1940, edited by Stephen Hirsch and Lucien van der Walt. Leiden: Brill, 395-412. 
Howard, Neil and Keira Pratt-Boyden. 2013. "Occupy London as Pre-Figurative Political Action." Development in Practice 23:729-41.

Husted, E. 2015. "From Creation to Amplification: Occupy Wall Street's Transition into an Online Populist Movement." In Civic Engagement and Social Media: Political Participation beyond Protest, edited by Julia Udlam and Anne Vestergaard, 153-73. Baskingstoke: Palgrave.

Kaldor, Mary, Sabine Selchow, Sean Deel and Tamsin Murray-Leach. 2012. The 'Bubbling up' of Subterranean Politics in Europe. London: London School of Economics.

Kauffman, LA 2011. "The Theology of Consensus.” In Occupy! Scenes from Occupied America, edited by Astra Taylor, Keith Gessen and the editors from $n+1$, Dissent, Triple Canopy and The New Inquiry, 46-8. London: Verso,

Kerton, Sarah. 2012. "Tahrir, Here? The Influence of the Arab Uprisings on the Emergence of Occupy." Social Movement Studies 11:302-8.

Kinna, Ruth. 2015. "Kropotkin's Theory of the State: A Transnational Approach." In Reassessing the Transnational Turn: Scales of Analysis in Anarchist and Syndicalist Studies, edited by Constance Bantman and Bert Altena, 43-61. London: Routledge.

Kinna, Ruth. 2019. The Government of No One. London: Penguin Books.

Kinna, Ruth and Alex Prichard. Forthcoming. "Anarchism and Non-Domination." Journal of Political Ideologies.

Kropotkin, Peter. n.d. [1885]. "Le Gouvernement Représentatif." In Parole d'un Révolté, edited by Elisée Reclus, 169-212. Paris : Librairie Marpon et Flammarion.

Kropotkin, Peter. 1906. The Conquest of Bread. London: Chapman and Hall.

Kropotkin, Peter. 1988 [1886]. "The Coming Revolution.” In Act for Yourselves, edited by Nicholas Walter and Heiner Becker, 19-23. London: Freedom Press.

Kropotkin, Peter. 1988 [1887]. "The End Set before Us.” In Act for Yourselves, edited by Nicholas Walter and Heiner Becker, 47-51. London: Freedom Press

Knapp, Michael, Anja Flach and Ercan Ayboga. 2016. Revolution in Rojava: Democratic Autonomy and Women's Liberation in Syrian Kurdistan. London: Pluto Press.

Lindahl, Hans. 2007. "Constituent Power and Reflexive Identity: Towards an Ontology of Collective Selfhood." In The Paradox of Constitutionalism, edited by Martin Loughlin and Neil Walker, 9-24. Oxford: Oxford University Press.

Liu, Yvonne Yen. 2012. "Where Is the Color in Occupy?” In We Are Many: Reflections on Movement Strategy from Occupation to Liberation, edited by Kate Khatib, Margaret Killjoy and Mike McGuire, 75-80. Oakland, CA: AK Press.

Loughlin, Martin. 2014. “Constitutional Pluralism: An Oxymoron?” Global Constitutionalism $3(1): 9-30$.

Loughlin, Martin and Neil Walker. 2007. The Paradox of Constitutionalism: Constituent Power and Constitutional Form. Oxford: Oxford University Press.

Maeckelbergh, Marianne. 2009. The Will of the Many: How the Alterglobalisation Movement Is Changing the Face of Democracy. London: Pluto Press.

Maeckelbergh, Marianne. 2011. "Doing is Believing: Prefiguration as Strategic Practice in the Alterglobalization Movement." Social Movement Studies 10:1-20.

Maeckelbergh, Marianne. 2013. "Learning from Conflict: Innovative Approaches to Democratic Decision Making in the Alterglobalisation Movement." Transforming Democracy 21:27-40.

Maiguashca, Bice, Jonathan Dean and Dan Keith. 2016. "Pulling Together in a Crisis? Anarchism, Feminism and the Limits of Left-Wing Convergence in Austerity Britain." Capital \& Class 40:37-57.

Marx, Karl and Frederick Engles. 1848. The Communist Manifesto. Available at: <https:// www.marxists.org/archive/marx/works/1848/communist-manifesto/index.htm>. 
Mason, Paul. 2016. Postcapitalism: A Guide to Our Future. Houndmills: Macmillan.

Maximov, Grigori Petrovitch 1985. [1927] Program of Anarcho-Syndicalism. Sydney: Monty Miller Press.

Michels, Robert. 1966 [1911]. Political Parties: A Sociological Study of the Oligarchical Tendencies of Modern Democracy. New York, NY: Free Press.

Mouffe, Chantale. 2013. Agonistics: Thinking the World Politically. London: Verso.

Peräkylä, Annsi and Johannna Ruusuvuori. 2011. "Analyzing Talk and Text.” In The Sage Handbook of Qualitative Research (4th edn), edited by Norman K. Denzin and Yvonna S. Lincoln, 529-43. London: Sage.

Pettit, Philip. 1997. Republicanism: A Theory of Freedom and Government. Oxford: Clarendon.

Pickerill, Jenny and John Krinsky. 2012. "Why Does Occupy Matter?” Social Movement Studies 11:279-87.

Pleyers, Gregory. 2012. "Beyond Occupy: Progressive Activists in Europe.” In Open Democracy: Free Thinking for the World (8 October).

Prichard, Alex. 2013. Justice, Order and Anarchy: The International Political Theory of PierreJoseph Proudhon. Abingdon: Routledge.

Prichard, Alex. 2017. "Collective Intentionality, Complex Pluralism and the Problem of Anarchy." Journal of International Political Theory 13:360-77.

Proudhon, Pierre-Joseph. 1994. [1840] What Is Property? An Inquiry into the Principle of Right and of Government, translated by Donald Kelley and Bonnie Smith. Cambridge: Cambridge University Press.

Proudhon, Pierre-Joseph. 1989. [1851] General Idea of the Revolution in the Nineteenth Century. London: Pluto Press.

Proudhon, Pierre-Joseph. 1979. [1863] The Principle of Federation, or the Need to Reconstitute the Party of the Revolution, translated and introduced by Richard Vernon. Toronto: University of Toronto Press.

Proudhon, Pierre-Joseph. 1870. Contradictions politiques: théorie du mouvement constitutionnel an xixe siècle. Paris: A. Lacroix, Verboeckhoven et Co.

Rippon, The Rt Hon. Lord of Hexham QC. 1990. "Constitutional Anarchy." Statute Law Review 11:184-8.

Rossdale, Chris and Maurice Stierl. 2016. "Everything Is Dangerous: Conduct and Counterconduct in the Occupy Movement." Global Society 30:157-78.

Savio, Gianmarco. 2015. "Coordination outside Formal Organization: Consensus-Based Decision-Making and Occupation in the Occupy Wall Street Movement." Contemporary Justice Review 18:42-54.

Schneider, Nathan. 2013. Thank You, Anarchy: Notes from the Occupy Apocalypse. Berkeley, CA: University of California Press.

Schrager, A. and Daniel Lang/Levitsky. 2012. "The Politics of the Impossible." In Dreaming in Public: Building the Occupy Movement, edited by Amy Schrager and Daniel Lang/ Levitsky. Oxford: New Internationalist Publications Ltd, 15-25.

Seale, C. 1998. Constructing Death: The Sociology of Dying and Bereavement. Cambridge: Cambridge University Press.

Shaw, F. 2012. "'I Act as the Tongue of You': Open Source Politics and the Occupy General Assembly." The Australian Sociological Association's 2012 Conference Proceedings: Emerging and Enduring Inequalities.

Skinner, Quentin. 1969. "Meaning and Understanding in the History of Ideas." History and Theory 8:3-53.

Some Oakland Antagonists. 2012. "Occupy Oakland Is Dead. Long Live the Oakland Commune!" In We Are Many: Reflections on Movement Strategy, edited by Kate Khatib, Margaret Killjoy and Mike McGuire, 409-16. Oakland, CA: AK Press. 
Springer, Simon. 2011a. "Violent Accumulation: A Postanarchist Critique of Property, Dispossession, and the State of Exception in Neoliberalizing Cambodia." Annals of the Association of American Geographers 103:608-26.

Springer, Simon. 2011b. "Public Space as Emancipating: Meditations on Anarchism, Radical Democracy, Neoliberalism and Violence." Antipode 43:525-62.

Srnicek, Nick and Alex Williams. 2015. Inventing the Future: Postcapitalism and a World without Work. London: Verso.

Swann, Thomas and Konstantin Stoborod. 2014. "Editorial: Did You Hear the One about the Anarchist Manager?” Ephemera: Theory \& Politics in Organization 14:591-609.

Swann, Thomas and Emil Husted. 2017. "Undermining Anarchy: Facebook's Influence on Anarchist Principles of Organization in Occupy Wall Street." The Information Society 33:192-204.

Szolucha, Anna. 2017. Real Democracy in the Occupy Movement. London: Routledge.

The Guardian. 2011 "Occupy Protests around the World: Full List visualised" (14 November). Available at: <https://www.theguardian.com/news/datablog/2011/oct/17/occupyprotests-world-list-map $>$.

Tuck, Richard. 2015. The Sleeping Sovereign: The Invention of Modern Democracy. Cambridge: Cambridge University Press.

Tully, James. 2002a. "Political Philosophy as a Critical Activity." Political Theory 30:533-55.

Tully, James. 2002b. "The Unfreedom of the Moderns in Comparison to Their Ideals of Constitutional Democracy." The Modern Law Review 65:204-28.

Tully, James 2007. "The Imperialism of Modern Constitutional Democracy.” In The Paradox of Constitutionalism, edited by Martin Loughlin and Neil Walker, 315-38. Oxford: Oxford University Press,

Van der Walt, Lucien and Michael Schmidt. 2009. Black Flame. The Revolutionary Class Politics of Anarchism and Syndicalism. Edinburgh and Oakland, CA: AK Press.

Vincent, K. Stephen. 1984. Pierre-Joseph Proudhon and the Rise of French Republican Socialism. Oxford: Oxford University Press.

Waldron, Jeremy. 2016. Political Political Theory: Essays on Institutions. Cambridge, MA: Harvard University Press.

Walter, Nicholas. 1969. “About Anarchism.” Anarchy 100:161-92.

Ward, Colin. 2004. Anarchism: A Very Short Introduction. Oxford: Oxford University Press.

White, Stuart. 2017. "Parliaments, Constitutional Conventions, and Popular Sovereignty." British Journal of Politics and International Relations 19:320-35. 